\title{
ACRL in Washington, D.C. ACRL programs at the ALA Annual Conference
}

\begin{abstract}
A LA's 129th Annual Conference was held June 24-29, 2010, in Washington, D.C. Approximately 26,000 librarians, library support staff, exhibitors, writers, educators, publishers, and special guests attended the conference. Ed. note: Thanks to the ACRL members who summarized programs to make this report possible.
\end{abstract}

\section{Using primary sources}

The aim of the Asian, African, and Middle Eastern Studies (AAMES) program, entitled "Teaching AAME Resources by Using Primary Source Materials from Special Collections," was to promote using primary sources from special collections and Web 2.0 technologies for teaching bibliographic instruction sessions to students of Asian, African, and Middle Eastern Studies.

The panel had two moderators and five speakers. AAMES Chair Anjana H. Bhatt (Florida Gulf Coast University) opened the session by welcoming the attendees and speakers. Chellammal Vaidyanathan (Johns Hopkins University) and Tara Lannen-Stanton (Queens Library) introduced the speakers to the audience.

The first presentation, "Teaching African Resources with a Primary Source Focus in African Studies Library Instruction," was presented by David Easterbrook (Northwestern University). His presentation focused on many digital primary resources on African Studies used by Northwestern classes.

Mary Jane Deeb's (Library of Congress) presentation "African and Middle Eastern Primary Source Materials at the Library of Congress That Can Be Used for Teaching," highlighted valuable materials from the digital resources and special collections at the Library of Congress.

Shuyong Jiang (University of Illinois at Urbana-Champaign) and Tao Yang (Rutgers University) presented the third presentation "Web 2.0 and East Asian Librarians." Their presentation concentrated on the use of Web 2.0 technology in promoting East Asian resources and providing services.

The final presentation, "Resourcefully Vying for our User's Attention with Library's Primary Sources" was presented by Triveni Kuchi (Rutgers University), the incoming AAMES chair for 2010-11. In her presentation, Kuchi addressed the significance of librarians co-creating value with the users and the library's primary resources by theoretical analysis and practical examples.

Most of the presentations can be accessed at www.ala.org/ala/mgrps/divs/acrl/events /acrlatannual.cfm.-Qian Liu, Arizona State University, qian.liu.2@asu.edu

\section{Sequenced learning}

"How do you peel a banana?" This was the question keynote speaker David Loertscher used to kick off the panel session "Sequenced Learning," sponsored by the AASL/ACRL Interdivisional Committee on Information Literacy. Throughout this engaging session, Loertscher challenged attendees to use 180-degree thinking, or in other words, try peeling the banana from the bottom up (which turns out to be much easier).

Loertscher pushed attendees to think beyond the traditional boundaries of information literacy and emphasized the need to 
broaden our interpretation of 21st-century skills. He suggested fostering collaborative intelligence in students, which helps to drive the creation of new ideas and prevents students from disengaging.

Next, panelists representing K-20 levels talked about how 21st-century skills are taught in their respective settings. Karen Lemmons (Howe Elementary School, Detroit) demonstrated some of her techniques, which incorporate the AASL standards and draw upon students' school curricula. She emphasized sparking the students' curiosity as a way to drive information-seeking behaviors.

Valerie Diggs (Chelmsford High School, Massachusetts) stressed that students in grades 9 to 12 often only come to the library on an as-needed basis and not as part of a class. As resources and technology change, a cquiring multiple literacies becomes more critical, and she emphasized creativ-

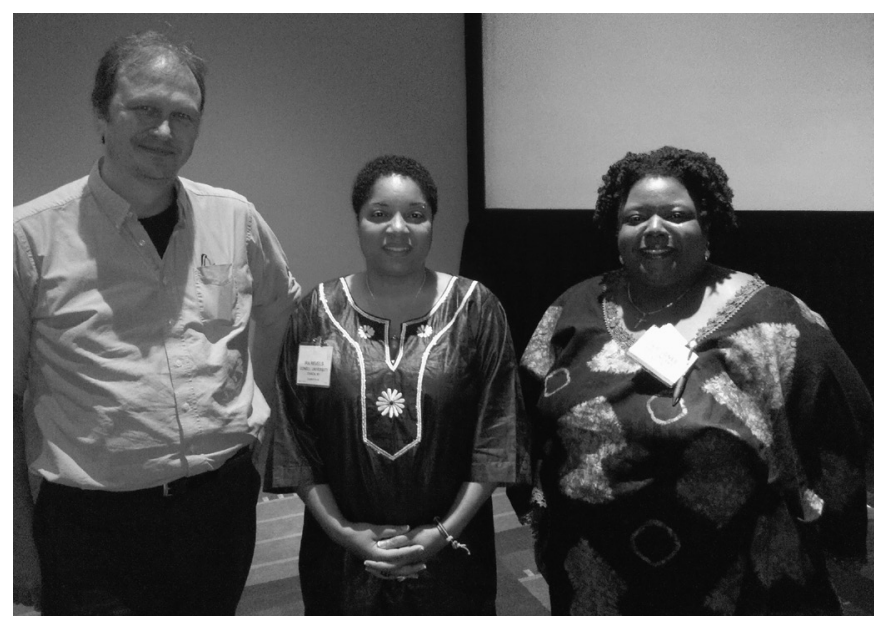

Presenters of the AFAS program, "Digitization: Preserving and Open Access to African American Collections."

\section{Digitization}

The African American Studies Librarians Section (AFAS) sponsored a session titled "Digitization: Preserving and Open Access to African American Collections." AFAS Chair Vivian Fisher welcomed the audience of more than 100 and thanked cosponsor ProQuest. ProQuest Senior Product Manager Sarah Brechner discussed new and continuing products and the recent creation of a new Spectrum Scholarship, named for the late and long-time ProQuest employee Ron Clowney. Program planning committee member Johnnieque B. Love provided an overview of the session, then introduced the speakers, Ida Jones, (Howard University's Moorland Spingarn Re- ity in teaching and personalization of assignments to ensure students acquire new skills.

Lastly, Ellysa Stern Cahoy (Library Learning Services, Penn State) discussed building digital literacies through multimedia assignments. Cahoy highlighted a recent research study, where she explored the impact of the librarian's involvement in a multimedia assignment.

One key finding was students reported feeling most daunted by using new technologies for video creation over any other aspect of the assignment.

Panelists' presentations can be found at www.bit.ly/infolit._Emily Rimland, Penn State,erimland@psu.edu search Center), Robert Cox (University of Massachusetts [ UM ] - A m herst), and Ira Revels (HBCU Alliance-Cornell University Digitization partnership).

Jones discussed the digital projects the center has created, including a South African Project that is a partnership with South African archives and Howard University, the preservation of Howard University's electronic journal (HUArchivesNET) started in 1999, and working to digitize the oral histories of university donors. Cox discussed UM's multipart digital project that seeks to provide unique access to the papers of W.E.B. DuBois. The project includes links to DuBois Online and a DuBoisopedia, similar to Wikipedia, which that will allow viewers to add to the scholarship on DuBois. Cox spoke about the desire to expand research on DuBois and to encourage collaboration with new and young 
scholars. Revels discussed the HBCU Library Alliance's project that seeks to digitize the collections of historically Black colleges and universities. Revels discussed the planning, selection, marketing, and analysis process that are essential to the development of digital projects.-Rebecca Hankins, Texas AGM University,rhankins@tamu.edu

\section{Libraries and social change}

A healthy turnout enjoyed the Anthropology and Sociology Section's (ANSS) Sunday morning program, "Standing Up and Sitting In: Libraries and Social Change." Moderator Annie Paprocki introduced the three panelists: Cheryl Knott Malone (University of Arizona), John Feffer (Institute for Policy Studies in Washington, D.C.), and Kathleen de la Pena McCook (University of South Florida). Malone kicked off the session discussing the history of the desegregation of southern public libraries. Malone advocated for using history to inform our current practices; although the history of the desegregation of schools is well known, she argued, the story of the desegregation of public libraries is often overlooked. It is worth contemplating Malone's point that libraries have the ability not just to provide access to resources, but also to obscure the wealth of resources and information in the world if they do not push the open sharing of information and promote a wide range of resources to our communities.

Feffer carried Malone's momentum, speaking on "Provisions Library and The Balkans Project," stating that Provisions Library's central mission is subversion, manifested through "revelation, provocation, and transformation." The Balkans Project continues this mission, bringing together artists, activists, and intellectuals from the Balkans, Latin America, and the United States to create collaboration around the conflict in the Balkans, as well as the oppression of many peoples of the world.

McCook capped the panel, discussing libraries and library collections supporting social change, civil rights, and human rights, from rogue librarians in the 1920s who established the anarchist collection at the UM, to the ALA's decision in the 1960s to not hold conferences in the segregated South. She also highlighted many individual librarians who have fought against censorship. For more info, see anssdc.wordpress.com/_Miriam Rigby, University of Oregon, rigbym@gmail. com

\section{How we memorialize}

The Arts Section program, "How We Memorialize," explored the definition of memorials, why societies erect them, and the controversies surrounding them. Kirk Savage (University of Pittsburgh) says societies erect memorials to "preserve or perpetuate a memory," which is why "imperishable materials are used" in their creation. He focused on the memorials of Washington, D.C., which he calls the "heart of the memorials of the nation." Savage is the author of articles and books, included in the session bibliography and available on the Arts Section Web site.

His most recent book Monument Wars won the Smithsonian American Art Museum's 2010 Charles C. Elderedge Prize for Distinguished Scholarship in American Art. Savage talked about monuments as "communal ritual," saying they have their "own agenda as self-promotion of a group's ideas." If the "monument manufactures its own aura," then why can't it be ephemeral rather than permanent?

Savage's presentation merged with that of speaker Davis Buckley. Davis Buckley Architects and Planners have designed numerous memorials, including the National Law Enforcement Officers Memorial and the National Japanese-American Memorial to Patriotism During World War II, which commemorates those Americans interned in camps in 1942. Buckley surveyed the Japanese-American community forming focus groups to hear their stories and to find out what a memorial meant to them. Part of the memorial process in Washington, D.C., is approval for the location and construction of the memorial. Buckley said, "a memorial is a negotiating process" and "you totally 
have to believe in it." He was chosen to design the memorial because the JapaneseAmerican community knew he would listen and be unbiased.

The program had more than 50 attendees, going overtime with many questions. Following the program, which was generously supported by ArtStor, some attendees toured the Japanese partiotism memorial with Buckley.-Tara Spies Smith, Texas State University-San Marcos, Ts20@txstate.edu

\section{Transitioning students}

Alice Lubrecht (now State Librarian of Pennsylvania) led a panel of participants looking at the issue of transitioning students from high school to and through college in the Community and Junior College Libraries Section (CJCLS) program "Yours, Mine and Ours." Three ongoing collaborative projects were described, followed by a presentation on assessment to determine what is working.

Megan Oakleaf (Syracuse University) and Patricia Owen (Eastwood Schools of Pemberville, Ohio) opened the session with an overview of their project, which aimed for shared goals and standards. They were especially interested in bridging the gap between grade 12 and the college level, where it appears that expectations on the part of faculty are not being met in terms of what skills students display. Several handouts of articles by Oakleaf and Owens were available for attendees.

Patti Pfau (Harford Community College) advised that college librarians need to know the high school curriculum and work to collaborate with other librarians to be sure that there is appropriate communication between the high schools and the colleges.

Tom Reinsfelder (Penn State-Mont Alto), Jill Thompson (Greencastle-Antrim School District), and Diane Strock (Waynesboro Area Sr. High School) discussed working with the dual credit community. Trips to the college library helped students experience the differences and become informed before setting foot on campus for actual classes. They encouraged the audience to look to grants to fund programs and to provide more computers to the schools.

Ken Burhanna (Kent State) offered comments on assessing the effectiveness of such programs. Stressing "informed transitions," he said assessment is critical for success in teaching, learning, and accountability. He encouraged collaboration among librarians at all levels, telling us to "bring the players to the table." Because our cultures can be different, finding better formats for communication is key to the success of any program that aims to transition students successfully from the high school to the college level.-Christine Crowley, Northwest Vista College, ccrowley5@ alamo.edu

\section{Librarians just need to have fun}

The College Libraries Section (CLS) chose a lighthearted theme with important implications for the conference program titled "Librarians Just Need to Have Fun." Attendees gathered to the sounds of The Beach Boys, while tossing beach balls, blowing bubbles, and shaking noisemakers. Ann Watson (moderator and chair of the Program Planning Committee) opened the program and welcomed its panel of four speakers, all of whom have used games, morale-boosters, and programs to improve employee performance.

Erin Davis (Utah State University) designs events and programs that emphasize training, education, and retention through fun competition and ongoing appreciation for dedicated employees with her Staff Development Committee. An annual Staff Day includes a Library Olympics. In one competition, the winning staff member loaded a microfilm reader faster than the other participants.

Teresa Doherty (Virginia Commonwealth University) uses games and activities to reduce hierarchical barriers that can keep colleagues from feeling comfortable with one another. One competition challenges staff from all departments, including the university librarian, to a shelf reading competition.

Pat Van Zandt (Southern Methodist University) plans motivational programs she 
develops through campus connections. A past event featured a baking demonstration with the campus pastry chef. Others have presented valuable life and work skills, such as CPR training.

Frances Yates (Eastern Indiana University) inspires creativity, allowing staff to simultaneously have fun and overcome challenges. Children's literature, crafts, and art projects all help employees find solutions through creative expression.

Preceding the program, Sigrid Kelsey and Angela VandenBroek (Louisiana State University) received the CLS ProQuest Innovation in College Librarianship Award for demonstrated commitment to creating and promoting the use of open-source content and resources.

For more information on the program and speakers, please visit www.ala.org/ala /mgrps/divs/acrl/events/acrlatannual.cfm and scroll down to the CLS section.-Jane P. Currie, Loyola University-Chicago, jcurrie@luc.edu

\section{Open access debate}

"The Open Access Debate: A Conversation," presented by the Distance Learning Section (DLS) and cosponsored by the LITA Distance Learning Interest Group and the ACRL Scholarly Communications Committee, brought together representatives from the publishing industry, NIH, an open access advocate, and a librarian with an active audience of mostly academic librarians.

Panelists Heather Joseph (Scholarly Publishing and Academic Resources Coalition), David Gillikin (National Library of Medicine), Dori Gardner (Elsevier), and Lia Hemphill (Nova Southeastern University) held an informative discussion that touched on the definitions of open access, the value publishers add to scholarly communication, barriers to information access, the NIH mandate, and other government efforts to promote or restrict publicly funded research.

After discussing the sharp rise in journal prices, Joseph illustrated the barriers to information access by quoting a conversa- tion with a researcher. "I realized I was missing about $1 / 3$ of all articles of interest," she remembers Gary Price saying, "which meant I was doing research on what I had access to, not what I wanted to know-and worse, I ended up teaching my students what I had access to rather than what they need to know."

Gardner emphasized the role publishers play in disseminating and archiving scholarly information and ensuring quality. In discussing various author/institution pays, sponsored articles, moving walls, and other methods of making Elsevier content more widely available, she emphasized the Elsevier is, ". . . pro universal dissemination, pro quality and pro sustainable publishing systems."

Panelists presentations and a video of the session, including the lively Q\&A session, is available through ALA Connect at connect. ala.org/node/100669. DLS would like to thank the panelists, our cosponsors, and the audience for the excellent Q\&A._Dan Gall, University of Iowa, daniel-gall@uiowa.edu

\section{News literacy and preservation}

Innovative ways to use social media in following and writing about top news stories was the leading presentation by Washington Post's Meg Smith at the Education and Behavioral Sciences Section's (EBSS) program "News Literacy and Preservation." Cosponsored by the Instruction Section (IS), with financial sponsorship from LexisNexis, the program addressed issues related to archiving and accessing news sources in various formats.

As a Washington Post researcher, Smith chronicled the powerful emotions evoked and ethical issues raised through using social networking media, such as Facebook, to get the latest information on the Virginia Tech shooting of 2007. She addressed the role of citizen journalism in breaking news stories, as individuals share information through social media. Hannah Sommers (National Public Radio) outlined the preservation issues for nontext formats, and the complex metadata 
that makes retrieval of news possible and timely. Bernard Reilly (Center for Research Libraries [CRL]), focused on the capture of news media in a digital age and the proactive monitoring and interventions that may be required. CRL collects unique items, such as South African anti-apartheid newspapers or French Vietnam War era papers, in its efforts to preserve news. Debra Cheney (Pennsylvania State University Libraries) provided a perspective from libraries working directly with students. She advocates re-establishing the library as a place for news content and instructing students in the difference between news and news commentary. The audience responded with questions about working with news media in a library setting, and instructing users and the public about ethical issues related to journalism.

Preceding the program was the presentation of the Distinguished EBSS Librarian Award to Penny Beile (University of Central Florida).-Nancy O'Brien, University of Illinois at Urbana-Champaign, npobrien@ illinois.edu

\section{Ethical considerations in library vendor relations}

At this year's Committee on Ethics program, "Last Fair Deal Gone Down," a panel addressed the complexities of librarian and vendor relationships. Program Chair Keith Powell introduced the program as a dialogue between the panelists and audience. Having been both a librarian and vendor, he reflected upon the interesting dynamics between these parties, arguing that such relationships are often quite complex.

Ivy Anderson (California Digital Library) emphasized the importance of judgment, clear communication, and institutional policy. She considered gifts to be acceptable, but only if inexpensive and impersonal, and not within the context of a purchasing decision. She recommended librarians have documented evaluation processes, decision criteria, and timelines for purchasing decisions. Ethics documentation and training, as well as seeking guidance from compliance officers when needed, can also benefit librarians in guiding decision making. Ultimately, she argued that common sense is the best guide.

Kittie Henderson (EBSCO) shared the vendor perspective. She argued that gifts and meals are for thanking clients and continuing conversations, not obligating them to make a purchase. There was debate over more expensive, personal gifts and when these are appropriate. She discussed transparency to show that vendor products are receiving fair evaluations; Anderson suggested this be ensured through purchasing policy and multiple levels of review. Henderson advocated for realistic expectations on both sides, and suggested summarizing discussions in writing.

Margaret Mellinger (Library à la Carte) concluded the program by discussing open source software and its ethical ramifications, including how it aligns with the ALA Code of Ethics. At the heart of open source is community, and participation and shared expectations are necessary for its success.

Throughout the program, the panelists and audience members engaged in discussion, sharing their own experiences. The overarching themes were transparency in communication, following institutional policy, being fair, and not allowing gifts to influence sound decision making.- $R e$ becca Blakiston, University of Arizona, blakistonr@u.library.arizona.edu

\section{Using LibGuides as a platform for student research}

"Beyond Library Guides" drew an audience of 177 people. Phyllis Conn (St. John's University) copresented with Benjamin Turner (St. John's University Libraries).

Turner opened the presentation by comparing the benefits and drawbacks of using LibGuides as a research platform compared to freely available wiki software, such as Wikispaces and PBWiki. Advantages of LibGuides include its relative stability, easy integration with other LibGuide content, and university branding and lack of advertising. 
Disadvantages of LibGuides include lack of version control, which allows easy reversion to earlier versions of a wiki. Another disadvantage of LibGuides is that it does not indicate which contributor created specific content, which provides less flexibility in grading collaborative writing projects. Furthermore, although LibGuides can be easily backed up, it is harder to restore content that might be accidentally deleted by a contributor.

Conn then discussed best practices for incorporating LibGuides or wikis in student research assignments. Her recommendations included defining clear learning goals, understanding the strengths and weaknesses of the platform to be used, deciding how students' work will be evaluated and whether students will work in groups or individually, providing basic architecture for the site, and how to cope with technical challenges faced by students. Conn also recommended the team teaching approach, either between faculty member and librarian, or between two teaching faculty members.

The session ended with attendees working in small groups to design a research assignment that incorporated either a LibGuide or wiki. The assignment would include learning goals, architecture for the wiki, whether students would work individually or in groups, and would indicate which source material students would use for their research.

-Benjamin Turner, St. John's University, turnerb@stjohns.edu

\section{Off site instruction}

"Library Instruction Live! Reaching Distance Students in Real Time" was presented by Sheila Bonnand (Montana State University), Nancy Connor (Cuyahoga Community College), and Mary Anne Hansen (Montana State University).

As attendee and reporter for this session, I had a very personal interest in this topic. My own library is exploring how to deliver library instruction to two off site campuses. The fact that the two schools represented are very different, with different needs, resources, and experience provided two valuable points of view. Montana State University is a small, rural land-grant university running its first pilot project, and Cuyahoga Community College is a large community college in urban Ohio, finishing up three years using Adobe Connect Pro.

While technology was discussed, the focus of the session was primarily on the why and how of making technology work for libraries and for delivering information literacy instruction. The session was very well attended, and the audience peppered the presenters with excellent questions related to time management, managing the "classroom" (using polls, welcome/entry pages, handling technology glitches on the fly, etc.), and big picture issues related to deciding to use this technology. Answers were based in experience and examples.

The demonstration portion was not as indepth or as successful as I had hoped, but it did give me a sense of what the software is like (presenters should consider a future workshop type session to provide hands-on experience). All three presenters made it clear that this is no magic bullet-successful information literacy instruction still relies on faculty buy-in, accountability requirements for students, and relevance to student work. The session did provide a much needed connection between interested parties and those who are doing it and making it work.Brenda Mathenia, University of Lethbridge, brenda.mathenia@uleth.ca

\section{What every new librarian needs to know}

Karen Sobel (University of Colorado- Denver) began the program "Starting Out? Start With You" with a question. She asked, "Who here has publishing among their job requirements?" Seeing a sea of hands she joked, "Yep, me too. It's listed as 30 percent of my job and amounts to about 80 percent of my stress."

She then offered up several helpful tips: 1) look for research questions in conversations with colleagues, things noticed on the 
job, and holes in the literature; 2) plan research efforts with your tenure requirements in mind-aim high when investigating journals/publishers and presentation opportunities; 3) look for collaborators in experienced colleagues, friends with similar professional interests, and faculty in other departments; 4 ) don't blow off the IRB, you may not get published without having received their preapproval; and 5) as for data, take a statistics class and ask for help from a professional—contact a statistician in your math department, ask for input early on, and bribe them with coauthorship.

Next, Lisa Carlucci Thomas (Southern Connecticut State University) challenged and encouraged audience members with straightforward tips for career success.

She advised, 1) know your talents and build expertise

in the direction you want your career to go- "read job ads like they're the news"; 2) establish an environment of collegiality within your institution-identify the good guys, value historical knowledge, and get involved; 3) professional associations need help ... volunteer; 4) "hanging out in your hotel room is not conferencing"be confident when introducing yourself; 5) create a professional portfolio before it matters; 6) invest an hour a week on moving your career forward; 7) stay current using alerts and social networks; 8) expand your lifelong peer group; 9) work outside your comfort zone; and 10) if you are unsatisfied, remember your current job isn't your career-chart your course and seek experience-building opportunities. -Carrie Bertling Disclafani, Towson University, cbertling@towson.edu

\section{Virtual classrooms-real instruction}

Attendees of the session "Virtually Embedded in Second Life" were treated to a multimedia presentation that focused on the dynamics of embedded librarianship for courses meeting in the virtual realm of Second Life. For novices and aficionados alike, this session provided an intriguing glimpse into the functionality, opportunities, and challenges of delivering instruction within a virtual environment.

University of Central Missouri (UCM) librarians Marian G. Davis and Carol Smith provided a detailed and insightful overview of this unique instructional service.

Davis offered a brief history of embedded librarianship at UCM, and described the events that ultimately partnered them with Bryan Carter (associate professor of English, UCM) to serve as librarians for his courses routinely conducted within Second Life.

While simultaneously providing a live tour of Second Life, the presenters discussed two significant challenges: 1) functioning within a virtual environment and 2) engaging students. New users must acclimate themselves to program functions and environmental features. As was demonstrated, avatar creation is a highly detailed process, and navigational skill development requires practice.

Issues with student engagement, discussed by Smith, were addressed by refining instructional content and employing active learning practices. Library instruction was delivered in brief, "digestible" segments dispersed over several course meetings. Topics included search strategies, interlibrary loan, and "power Googling."

The highlight of the presentation came when Carter joined the session live via 
Second Life to answer attendees' questions. With the help of Carter's avatar, Bryan Mnemonic, the presenters answered questions ranging from audio equipment and course expectations to administrative support and funding requirements.

Nearly 50 persons attended the presentation. A presentation Web guide and podcast are currently linked on the ACRL Web site at www.ala.org/ala/mgrps/divs/acrl/events /acrlatannual.cfm\#IP2.—Karla Massia, University of Central Missouri, kmassia@ucmo. $e d u$

\section{Technology and academic/research libraries in developing nations}

Six renowned library leaders from Egypt, Mexico, South Africa, and the United States addressed the theme "Technology and Academic Libraries in Developing Nations" in a well-received program.

Ellen Tise (International Federation of Library Associations and Institutions [IFLA]) presented plaques to each of the speakers in honor of their leadership roles in and contributions to international librarianship. Tise was also honored with a plaque presented by chair of the International Relations Committee and moderator of the session R. N. Sharma.

Addressing the digital gap between the libraries of developed and developing nations, the speakers discussed libraries in different geographic regions. Sohair Wastawy (Bibliotheca Alexandrina) traced the historical development of the library and highlighted intensive digital projects and partnerships currently underway. Ching-Chih Chen (Graduate School of Library and Information Science, Simmons College) spoke of the new challenges facing academic libraries in the information age and urged audience members to "thrive" not just survive. Jesus Lau (USBI VER Library at Universidad Veracruzana, Mexico) discussed the widespread adoption of new technologies by Mexican state universities. From the Library of Congress, Peter R. Young and Anchi Hoh provided an overview of the technological advances taking place in libraries across China, Japan, and Korea. Tise explored the "outer limits of international librarianship" with an emphasis on bringing the human dimension into the technological debate.

The program was cosponsored by ACRL's International Relations Committee, ACRL/ AAMES, ACRL/SEES, the Asian/Pacific American Librarians Association, the ALCTS International Relations Committee, the ALA International Relations Round Table, and the Chinese American Librarians Association. -Kathy Ray, American University of Sharjah, kray@aus.edu

\section{Translating evidence based practice to information literacy instruction}

Megan Oakleaf (School of Information Studies, Syracuse University) and Diana K. Wakimoto (California State University-East Bay) presented a program entitled "Question, Find, Evaluate, Apply. The program was sponsored by the Instruction Section (IS) and attended by more than 500 conference attendees.

The popular program showcased Evidence Based Practice (EBP) and how library instructors can apply it in their own research, classroom assessments, and to provide programmatic narrative. The presentation illustrated the striking resemblance between the cycle of EBP and the ACRL information literacy standards. However, the presenters suggested that libraries have not successfully created strong cultures of evidence within our systems. Unlike the area of medical research, where EBP originated, library/information studies have not done a good job of formally documenting the studies and assessments that would make up our evidence pool. With this lack of an evidence pool, EBP is more difficult to do. The speakers urged librarians to share their findings in order to build up our evidence pool. EBP can provide a strong foundation for libraries and librarians to address the increasing need to prove the value of our systems and services, and the impact of libraries on student learning.

The three "take aways" Oakleaf and Wakimoto wanted all attendees to leave with were 1) evidence is good and essential, 2) 
evidence trumps anecdotes, and 3) when in doubt, ask.

To see the presentation slides and bibliography of related sources, please visit bit.ly /awUZ5j.-Sheila Stoeckel, University of Wisconsin-Madison, sstoeckel@library.wisc.edu

\section{Participatory democracy in the Internet Age}

"Participatory Democracy in the Age of the Internet" was explored by Bryce Cullinane, (Institute for Politics, Democracy and the Internet at George Washington University), Decker Ngongang (Mobilize.org), and Dave Karpf (School of Communication and Information at Rutgers University) in a program sponsored by the LPSS. Cullinane identified three problems with political organizations becoming involved in the new technologies: thinking it is easy and cheap, targeting the wrong population of voters, and assuming it is free because "everything else on the Internet is." He discussed the relationship of time, tools, and consultants to ways of assessing Web use and suggested programs for this purpose, including Eventbrite, Vimeo, and UStream. He also strongly recommended reading publications by the Pew Foundation, WIRED magazine, and Fast Company.

Ngongang discussed the Millennials as a specific target population for politics and political scientists, arguing that young people suffer not from a lack of interest, but from a lack of access. He shared parts of a video from Mobilize.org that included the founder, David Smith, and several members of the Millennial generation sharing views on Democracy 2.0. Karpf explored unexpected transitions arguing that the new generation of political advocacy groups, such as the Daily Kos, Moveon.org, and the Progressive Change Campaign Committee, are prime examples of how organizations have developed and combine technology and nationwide communities of interest.

The uses of technology in politics were underlined during the Q\&A period. A member of the audience solicited opinions on the "Kill Switch" bill sponsored by Senator
Joseph Lieberman. All three of the participants turned immediately to their digital devices to discover the exact citation for the bill._Lynne Rudasill, University of Illinois at Urbana-Champaign, rudasill@illinois.edu

\section{Marketing ideas that work in academic libraries}

Two hundred and fifty-two librarians and library staff members attend "Pecha Kucha Presentations," hosted by the Marketing Academic and Research Libraries Committee (MARL) and moderated by Jennifer ChurchDuran and Toni Tucker.

The program highlighted real-life marketing strategies that worked in academic libraries of various sizes across the country. An opening panel discussion featured three librarians illustrating marketing campaigns that won either the ACRL Marketing Award or the John Cotton Dana Award. Mae Rodney (Winston-Salem University), Mary Fairbairn (Furman University), and Allen Lanham (Eastern Illinois University) provided dynamic overviews of their award-winning efforts. Lanham described the inventive use of ALA's traveling Frankenstein exhibit to launch a month-long series of curricular-based events, featuring faculty expertise from across the disciplines.

Rodney outlined innovative public relations and media techniques, including production of a music video, designed to introduce students to library services and facilities. Fairbairn explored a creative, medically themed program, "ICU: Life in the Library" and "Year of the Library," specifically orchestrated to ease students through disruptive construction and remodeling activities.

The second half of the program featured six speakers, presenting in a pecha kucha format (lightening round presentations). The speakers were Barbara Whitney Petruzzelli (Mount Saint Mary), Lynda Duke (Illinois Wesleyan University), Kerri Odess-Harnish (Gettysburg University), Maryke Barber (Hollins University), Carol Lee Anderson (University of Albany), and Selene Coburn (University of Vermont). 
Each speaker brought new ideas to the conversation, ranging from the importance of connecting outreach to education and curriculum; to enhancing campus/community engagement; to the use of ethnographic techniques in learning how to market to student; to viral marketing approaches, such as an "Ask campaign," which enlisted students as spokesmodels. The diversity of ideas and approaches in these rapid fire presentations left attendees with new ideas and new directions to purse in their own marketing and outreach endeavors.-Jennifer Church-Duran, University of Kansas, jgisme@du.edu

\section{Cataloging and the security of special collections}

The Rare Books and Manuscript Section (RBMS) presented its program "To Catch a Thief" to an audience of about 250 people.

The theme running through all four presentations was the importance of records - particularly catalog records-in the deterrence of book, map, and archives theft, in the apprehension of a thief when a theft does occur, and in the identification of stolen items.

Travis McDade (University of Illinois College of Law and author of The Book Thief) presented three case studies in which library catalogs played a role. He emphasized the importance of libraries marking their material but also, if they have experienced a theft, of vigorously prosecuting the culprit in court.

Mark Dimunation (Rare Books and Special Collections Division, Library of Congress) began by saying that our automobiles often have better documentation than our rare materials do. He believes that full-level catalog records can be instrumental in deterring theft and determining ownership—-but that such records are impractical in an era of fewer resources. One solution would be to have different levels of cataloging detail for different levels of material; the most valuable items would receive the most elaborate cataloging.

Bonnie Magness-Gardiner (FBI Art Theft Program) spoke about the work of the FBI Art Theft Program, which also investigates thefts of rare books and special collections materials. She said that in the United States, the market in cultural items is unregulated and documents are not required for them, as they are for automobiles or houses. She listed a number of recommended security measures, the first of which was inventory and cataloging.

Jennifer Schaffner (OCLC Research-RLG Partnership) talked about the missingmaterials. org project, which gives libraries, archives, and booksellers a centralized, highly visible place (connected to the shared OCLC cata$\log$ ) to list items missing from their collections.-Ellen Ellickson, Yale University, ellen. ellickson@yale.edu

\section{Cowriting across disciplines}

ACRL's Research Planning Committee engaged panelists and program participants in a lively discussion on the challenges and opportunities inherent in cross-disciplinary research collaborations in its program "It Takes Two."

The panel included Sheril Hook (University of Toronto-Mississauga), John Budd (School of Information Science and Learning Technologies, University of Missouri), Nicole Saylor (University of Iowa Libraries), and James Elmborg (School of Library and Information Science, University of Iowa).

Hook and Budd discussed their partnership with Paulette Rothbauer (University of Western Ontario) to identify the initial impacts of information literacy education. They attributed their successful collaboration in part to the shared need to address a common problem. They also highlighted the importance of developing good communication strategies, setting timelines, and following through on assigned tasks.

Saylor and Elmborg addressed the challenges of transforming a project from "proof of concept" to an established institutional presence. Elmborg's early involvement in the multiyear project (digitizing recordings of literary events for delivery through a library interface) led to a partnership with Digital Library Services. Elmborg spoke of framing his proposed collaboration so that it resonated with the Digital Library Services' interest in 
teaching initiatives. This partnership was instrumental in the maturation of the project.

Other key advice from speakers included:

- Pursue collaborations strategically. Ensure the partnership is a good use of time.

- Agree early on as to when and where to publish.

- Identify writing mentors. Find others publishing in your field and solicit their advice.

- Acknowledge and leverage the unique expertise that individuals bring to the project.

- Approaches to collaborative writing vary. Choose an individual to draft the article to ensure a "single voice" and/or allocate writing by area of expertise.

- Be cognizant of campus politics and the challenges they present.-Deborah Joseph Schmidle, Cornell University, dj13@cornell.edu

\section{Globalization and interdisciplinary studies}

The Slavic and East European Section (SEES) presented a provocative and well-attended program, "Area Studies Librarianship: Globalization and Interdisciplinary Studies in Today's and Tomorrow's Academic and Research Libraries."

Speakers included Maria Carlson (University of Kansas), Dan Hazen (Harvard College for Collection Development, Harvard University), and James G. Neal (Columbia University). The panel was moderated by Beverly Lynch (UCLA Professor of Information Studies, UCLA Senior Fellows Program and the California Rare Book School), and Jon Giullian (University of Kansas).

The discussion was an opportunity to reevaluate area studies librarianship. Carlson, who presented on this topic at the ALA Annual Conference in 1998, was able to provide context for the enormous changes that have occurred in the profession. She noted that predictions she made a decade earlier-that area studies would remain viable, while at the same time becoming more interdisciplinary, had proved accurate- and that events in the Balkans and the Middle East had demonstrated how necessary area specialists remain to our understanding of the world.
Hazen addressed the difficulty of supporting area and global studies because of the "fuzzy boundaries" among disciplines and the broad kinds of data that are now necessary for scholarship. Hazen stressed that the mission of a university library's collection development policies remained the same. He also commented on the sophisticated skill sets area studies librarians possess, and how scholarship would be affected if these positions were lost.

Neal provided an overview of trends in North American research libraries. Most importantly, he noted that these institutions were "collectively and systematically reducing their commitment and capacity to collect, organize, service, share, and preserve global publications and resources in all formats."

Neal challenged the profession to find areas in which they could coordinate and collaborate on collection development, citing the recent 2CUL project between Columbia and Cornell._Marta Mestrovic Deyrup, Seton Hall University Libraries, marta.deyrup@shu.edu

\section{Federal friends}

This year's Science and Technology Section (STS) program "Federal Friends: Creating Greater Access to and Support for Science and Technology Information" brought together experts from six different federal science and technology agencies to highlight a spirit of cooperation among government information agencies. Karen Vargas (National Network of Libraries of Medicine) moderated.

Vargas began with an overview of the National Network of Libraries of Medicine, highlighting both well-known online resources, such as PubMed and Medline Plus, and some lesser known resources, such as ChemIDplus and Genetics Home Reference. Michelle Cadoree Bradley (Library of Congress) gave a historical perspective on our national library that focused on rich aeronautical and astronautics holdings, technical and defense reports, and online subject guides called "Science Tracer Bullets." Cynthia Etkin (Federal Depository Library Program) emphasized interagency cooperative projects, such as DARTS (Depository Access to Reports, Technical and 
Scientific) with the National Technical Information Service and the National Climatic Data Center with the National Oceanic and Atmospheric Administration (NOAA). Tim Byrne (Office of Scientific and Technical Information, OSTI) showed how the Department of Energy is using cutting-edge search technologies and interfaces such as word clouds (like tag clouds), "More Like This," and clustering of results in its long list of OSTI search databases.

Doria Grimes (retired director of the National Oceanic and Atmospheric Administration [NOAA]) Central Library, described how the NOAA Library supports environmental and atmospheric research via cooperative ventures such as CENDI, an interagency working group of 14 federal agencies. Deborah Balsamo (Environmental Protection Agency National Library Network) discussed the importance of its digital archive in keeping the public informed about environmental issues.

Finally, all speakers emphasized that their agency libraries provide numerous training opportunities (online and in person) to librarians who wish to better use the information resources these libraries offer.-Edward J. Eckel, Western Michigan University, edward.eckel@wmich.edu

\section{Demonstrating excellence in higher education}

The panelists for the program "Demonstrating Excellence in Higher Education: What Universities are Doing. What Libraries are Doing," sponsored by the University Libraries Section (ULS), suggested that evaluating not only the products of our institutions but our institutions as a whole, will help us quantify the library's contributions to the research and learning of our organizations. Panel moderator Marilyn Myers (University of Houston) opened the program with a brief overview of some of the key points of the program.

Patricia Brennan (Thomson Reuters) discussed the use of data collection to evaluate the research at an institution. She mentioned
Thomson Reuters' Global Institutional profiles project as one possible tool to evaluate research at an institution on a global level.

Alexander C. McCormick (Indiana University) overviewed the current ways of evaluating an institution and suggested that institutional quality should be based not only on reputation and resources but also on teaching and learning. He mentions the NSSE (National Survey of Student Engagement) as one tool available to help evaluate the teaching and learning impact on students, as well as proving a positive relationship between library use and academic challenge.

The final panelist, J. Stephen Town (University of York), suggested libraries must create a culture of assessment in order to demonstrate their value. He mentioned the use of National Student Survey, in conjunction with other survey methods, as a way his library has been able to gather student views of their programs, facilities, and services. Town presented the idea of using comprehensive and holistic measurement to discover a library's "true worth."

There were approximately 175 attendees present and many had a strong interest in replicating the topic.-Karen Glover, Georgia Institute of Technology, karen.glover@ library.gatech.edu

\section{European fiction in translation}

It is generally acknowledged that in the era of globalization, migration across linguistic borders creates crosscultural awareness and increases the need for translated fiction. One might expect, therefore, that literary translations would constitute a sizable portion of the American publishing market.

According to the Translation Database (www.rochester.edu/College/translation /threepercent/index.php?s=database), however, last year only 355 current fiction and poetry titles from around the world were actually translated into English and published in the United States.

What do librarians need to know to build collections and promote European literature

(continued on page 423) 
3. Lisa German and Karen Schmidt, "Honoring Faculty: Book Plates to Celebrate Faculty Achievements," College \& Research Libraries News, 62, no. 11 (Dec. 2001): 1066-1067, 1130.

4. Donna Canevari de Paredes, "Gifts-inkind in the Academic Library: The University of Saskatchewan Experience," Library Collections, Acquisitions, and Technical Services, 30, no. 1/2 (March/June 2006): 55-68.

5. University of Colorado at Boulder Libraries, "Virtual Bookplate Policies and Procedure." Available online at ucblibraries.colorado.edu/collectiondevelopment /bmanual2/VIRTUAL\%20BOOKPLATES-\%20 final $\% 20$ draft $\% 204-1-08$. doc. [Accessed 8/11/10].

6. University of Maine Fogler Library, "Virtual Bookplates and Inscriptions." Available online at www.library.umaine.edu /techserv/Cataloging/Virtual_Bookplates.htm. [Accessed 8/11/10].

7. University of Pennsylvania Franklin Libraries, to see an example, catalog available online www.franklin.library.upenn.edu (search "glossberg fund"). [Accessed 8/11/10].

8. University of Michigan-Dearborn Mardigan Library, to see an example, catalog available online at wizard.umd.umich.edu (search "library donation 2009"). [Accessed 2/19/10].

9. "Electronic Books, Listed by Subject," LSU Health Sciences Center Medical Library, lib.sh.lsuhsc.edu/ebooks/ebooks.php. [Accessed 8/11/10].

10. Brown University Library, "Digital Bookplates." Available online at dl.lib.brown. edu/its/software/bookplates/. [Accessed 8/11/10].

11. Patricia Putney, Bonnie Buzzell, and Jean Rainwater, "Digital Bookplates: Using the OPAC for Stewardship in the Digital Age," Innovative Users Group Conference, April 2008, dl.lib.brown.edu/its/software/bookplates /Digital_Bookplates_final_noanimation.ppt. [Accessed 8/11/10].

12. An e-mail message with a link to a eight-page questionnaire on Survey Monkey was sent to three electronic lists: ACQNET (8/7/2009), AUTOCAT (8/6/2009), and LIB$\operatorname{DEV}(8 / 6 / 2009)$.

13. University of Florida Libraries, "Donor, Honoree and Special Purchases." Available online at http://www.uflib.ufl. edu/alephpro/catmet/donorguide.html [Accessed 8/11/10].

14. Samuel Huang, in a conversation with author (March 19, 2010).
("ACRL in Wash., D.C., cont. from page 414) in translation? What are the best sources for reviews of foreign fiction of potential interest to the American reading public? How are translations used in research and teaching? These questions, and more, were discussed by three distinguished panelists in the program "Contemporary European Fiction in Translation," moderated by Richard Hacken (Brigham Young University).

Chad W. Post (director of Open Letter Books and managing director of the Three Percent Web site) spoke about statistics, issues, and trends in the U.S. translation market.

Alane Salierno Mason (founder and president of Words Without Borders: An Online Magazine for International Literature, and vice president and senior editor at W. W. Norton \& Company) addressed cultural sen- sitivities needed in selecting and promoting writers from abroad.

Edwin Gentzler (Translation Center, University of Massachusetts-Amherst) provided an overview of the history of translation studies as a growing academic field.

All three panelists are in charge of substantial Internet sites on the various aspects of translation; a comprehensive list of links for further reading is provided at the program Web site at wess.lib.byu. edu/index.php/Upcoming_WESS_Conferences.

This event was cosponsored by the Western European Studies Section, Literatures in English, and Slavic and East European Section, and the panel was organized by a program committee chaired by Heidi Madden (Duke University) and Melissa VanVuuren (James Madison University)._-Heidi Madden, DukeUniversity, heidi.madden@duke.edu $n$ 